\title{
Deforestation: constructing problems and solutions on Sierra Leone's Freetown Peninsula
}

\author{
Paul G. Munro ${ }^{1}$ \\ Modelo University, Mexico
}

\section{Introduction: political ecology, deforestation and West Africa}

Perched on the northern edge of a mountainous forest peninsula, Freetown, the capital of Sierra Leone, is the only place in West Africa where forest-covered mountains meet the sea. From a distance it is an impressive sight, with the urban metropolis largely overshadowed by the backdrop of forested mountains. Yet, beyond this visual spectacle, a complicated relationship between Freetown and its surroundings persists. The pressures of the rapidly expanding city are taking an increasing toll on the forest expanse, with the fringes of the city rapidly pushing up into the mountains of the forested peninsula (Figure 1). Such an expansion is met with trepidation, as the forested area provides vital functions for the city, such as a catchment for water reserves and as a protector against natural hazards including landslides and flooding. Urban expansion is widely acknowledged as an issue by government officials and environmental groups, yet action to address these issues is lacking. The gap between the rhetoric surrounding the problems and the projects being implemented to address them is the subject of this paper. It will be argued that this gap can be understood by examining how different actors in Freetown involved in policy and projects interact over the issue of deforestation, and how this produces discourses of blame towards poorer, politically weaker groups, resulting in solutions that intervene in their lives.

The prescription of blame and solutions for deforestation on the Freetown Peninsula is negotiated through a combination of local realities, which includes the occurrence of deforestation, and global influences such as international development discourses and interventions. Years of authoritarian rule throughout the 1970s and 1980s and a subsequent ten-year civil war (1991-2001) destroyed much of Sierra Leone's physical infrastructure and many of its governance structures, leaving the country highly dependent on donor funding in the post-conflict era. This funding, filtered through the confines of international development agencies, has meant that external agents have had a great influence in defining local problems and solutions. A materialisation of this is the notion of 'sensitisation', a developmental idiom that refers to the top-down transfer of knowledge. Although this external influence is not absolute, rather 'development' creates an uneven geography of intervention that is a result of local realities and global perspectives. In Freetown the outcome is the existence of popularised understandings of how to prevent deforestation, that do not fit neatly with the actual occurrence of deforestation. This 'confused intersection' has created uneven applications of blame for deforestation, applications that construct the poor as either benign (yet ignorant) deforesters, or malign forest invaders. This paper ultimately explores nuances in the creation of these 'blame the poor' discourses and the subsequent actions that seek to intervene.

Underpinning this analysis is the assumption that deforestation is rarely a localised environmental issue. Numerous studies, mainly under the auspices of political ecology, have illustrated the complexity of deforestation; and in particular how it is often linked to broader economic, social and political issues (cf. R. Bryant 1997; J. Fairhead and M. Leach 1996a, 1998a; K. Sivaramakrishnam 1999). Political ecology has emerged in part from a structural Marxist framework, refuting simplistic determinism, and stressing the need for a greater recognition of the role that external factors and agents play in driving localised environmental problems and concerns. Political ecology seeks to dissect the differing levels upon which environmental problems and changes are influenced, providing research and analysis that accounts for relationships and influence not just at the local environmental scale.

James Fairhead and Melissa Leach are undoubtedly the most prolific researchers in utilising political ecology to examine the issue of deforestation in West Africa, having written articles, chapters and texts on the subject for over a decade (see J. Fairhead and M. Leach 1993, 1994, 1995a, 1995b, 1996a, 1996b, 1996c, 1998a, 1998b, 2000a, 2000b, 2002, 2003; M. Leach and J. Fairhead 2000a, 2000b, 2002). The majority of their work has focussed on savanna woodland, however, with only the more recent work including the 'closed canopy' humid tropical forest found on the Freetown peninsula (cf. Fairhead and Leach 1998a, 1998b Leach and Fairhead 2000b). Most renowned is their 1996 text Misreading the African Landscape, which is based on extensive fieldwork conducted in the Kissidougou region of Guinea. This work critically challenges the notion that Guinea's current forests are a relic of previous existing widespread

\footnotetext{
${ }^{1}$ Currently the author is a Lecturer in political science and international relations at Modelo University in Merida, Mexico. Email paul.g.munro "at" gmail.com. The research for this article was conducted for part of a MA in Environment and Development at King's College London.
} 


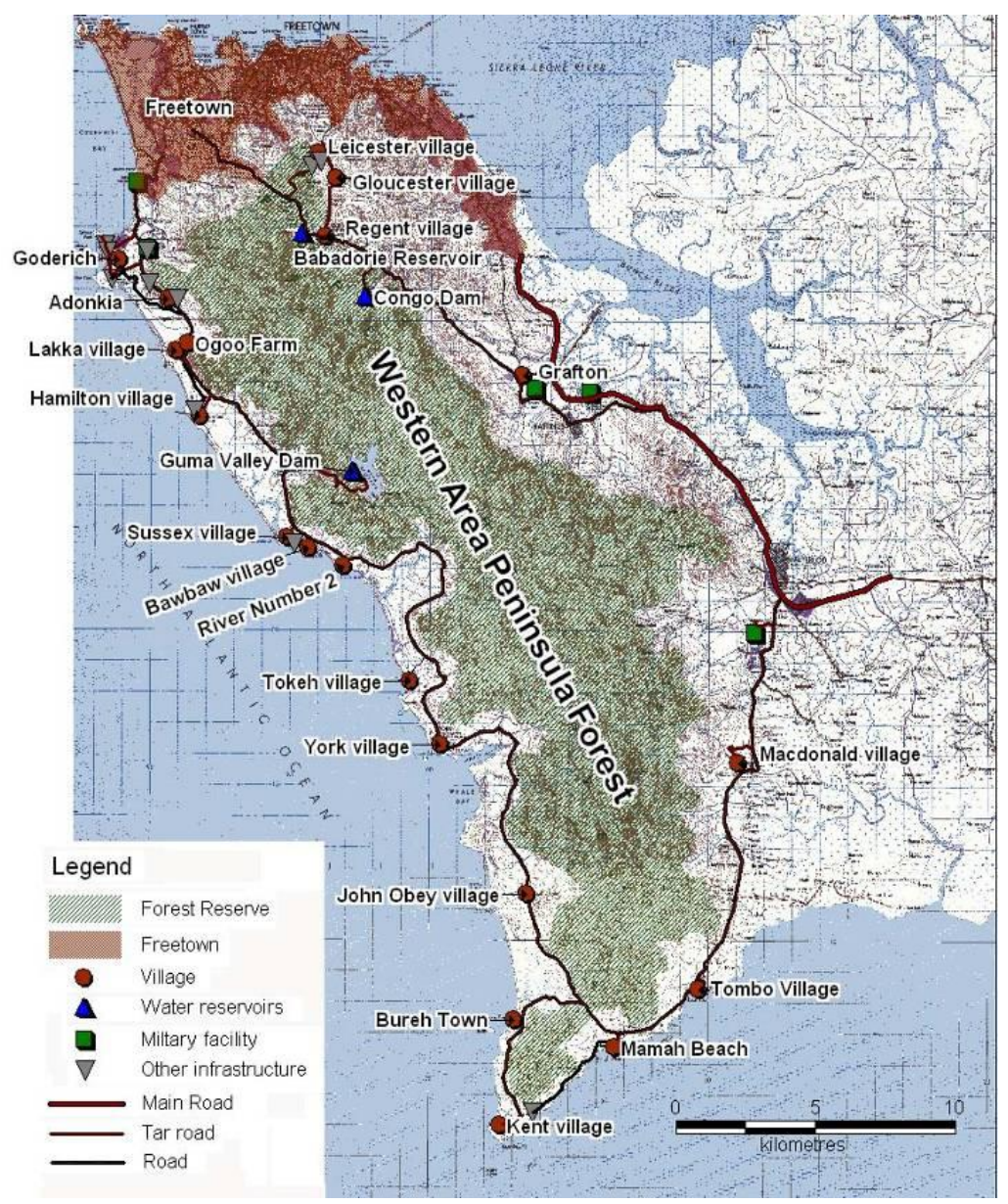

Fig. 1: Map of the Freetown Peninsula, showing Freetown and the Western Area Peninsula Forest. Source: E. Sesay 2005.

forest cover. Combining historical literature reviews and ethnographic research, they demonstrate how assumptions about Guinea's deforestation have been socially constructed over time, through the production of historical (invariably Western) 'scientific' myths, which continue to reinforce flawed or false data and perceptions. Their work is representative of a more recent turn in political ecology that draws increasingly from post-structuralist insights (cf. A. Escobar 1996; R. Peet and M. Watts 1996, 2004; P. Robbins 2004). A position that seeks not only to reveal the underlying political structures driving environmental degradation, but also to examine the influential discourses that shape the way these issues are perceived and subsequently addressed through policy. With this 'post-structuralist political ecology', a weak form of constructivism is generally assumed, the ontology being that a real world exists but ultimately we view it through our own constructed cognitive perspectives. Thus, environmental policy is not solely based on a clear perspective of the reality of environmental problems, but is also shaped and influenced by popular environmental ideas and perspectives. This presents us with the question: how are differing perceptions being reconciled with specific 'solutions' to deforestation?

The different views on deforestation proffered by influential actors based in Freetown, is the central concern of this paper. Thus a political ecology approach, informed by post-structuralist insights, provides a strong analytical basis from which to examine these dialectics. The paper does not attempt a description or an in-depth understanding of these different views but rather an examination on how they coalesce, shape and react to the environmental reality of deforestation on the Freetown Peninsula. There is a consensus from all actors that deforestation is occurring, but the perceptions of 'where it is happening', 'who is responsible' (for causing and preventing it) and 'how it is to be stopped' vary greatly. I attempt to integrate a structural focus on the state and society, as well as a poststructuralist attention to how interactions between such actors construct environmental discourses (T. Forsyth 2003). Thus the emphasis is not so much directed towards the more structuralist questions of whom, when or where blame is being applied for deforestation, for which 
there is near-consensus, but rather the more post-structuralist questions of how and why blame is being utilised.

This paper follows a trend increasing seen in human geography that recognises that qualitative studies of elites can help to inform understandings in an unequal world (see M. Crang 2002). By focusing on the perceptions and activities of so called 'urban elites', including Government Officials and NGOs based in Freetown who formulate policy and projects to 'address' deforestation, this research contributes to a greater understanding of how these actors interact to produce policies and outcomes surrounding the issue of deforestation. The urban elite are often discussed at a distance in political ecology literature, as the driving force behind deforestation and the creators of draconian, and often flawed, policies to prevent it. Such discussions homogenise the urban elite as a single entity with a shared identity. While much recent political ecological analysis of deforestation relies on the simple dichotomy of urban elites versus the rural poor, it is the intention of this analysis to unravel this homogenised identity, illustrating the complexity of power relations that characterise policy-making on deforestation in Freetown.

The field research for this article was carried out in Sierra Leone in June and July 2008, building on earlier work undertaken with environmental organisations in 2006 and 2007. The field research involved observations, interviews and visits to program sites within the research area and was conducted with various environmental NGOs. Twenty-three interviews were conducted in total with representatives from NGOs and different Government departments. All were involved in some way with the management or protection of forests on the Freetown peninsula. Snowballing techniques were utilised to identify the different participants interviewed, with at least one respondent interviewed from every Government department or NGO involved in policy and/or projects relating to the Peninsula forests.

This paper is presented in three distinct parts. The first analyses the historical circumstances of deforestation on the Freetown Peninsula. The second builds on this analysis and introduces contemporary actors relating to deforestation in Freetown, emphasising the nature of their interrelations and its relevance to deforestation issues. The third, divided into three thematic sections, builds on this contextual platform and examines the role that influential discourses, development activities (both in theory and praxis) and prescribed policy solutions have in shaping actions and perspectives towards deforestation.

\section{Freetown and its forest: the evolution of environmental concerns and solutions}

Concerns relating to the Peninsula forest began to emerge at the beginning of the twentieth century, when Sierra Leone was still a colony of Britain, with the colonial government employing two 'experts' from England to evaluate the state of the country's forests (A. H. Unwin and C. E. Lane-Poole). Both experts, in their subsequent reports, noted areas of forest destruction on the Peninsula, placing blame directly on the 'inefficient' and 'destructive' activities of the native population; with a particular emphasis on the Temne sawyers and canoe makers. As Unwin complained:

This reckless cutting is a most serious manner, as it menaces the very existence of the forest and is continually causing a reduction in its area (A. Unwin 1909:5)

In contrast, the logging activities of Europeans along the Peninsula were not criticised, and instead the construction of a saw-mill was suggested to make their production more efficient (see C. Lane-Poole 1911; A. Unwin 1909). ${ }^{2}$ Both reports recommended the establishment of a Forestry Department and a Peninsula forest reserve. Lane-Poole was also virulent in his criticism of the natives' shifting cultivation farming methods, which he deemed to be wasteful (C. Lane-Poole 1911; also see V. Buxton 1913). This disparaging position towards shifting cultivation has continued and has been the ire of many political ecologists (see M. Leach and R. Mearns 1996; A. Nyerges 1994; A. Ickowitz 2006). Fundamentally the rhetoric in these reports was about control, that the colonial government should imbue a more direct management system of the country's resources.

The impact of these reports was substantial and by 1912 a Sierra Leonean Forestry Department had been established (FD/SL 1913; also see Millington 1987). Prior to its establishment, upon the recommendations of Unwin (1909), a reforestation program had been enacted upon the 'denuded' landscape of Leicester Peak (the main mountain above Freetown), and its progress was tracked and evaluated meticulously by the Forestry Department in subsequent years (see FD/SL 1913-6, 1921). This Leicester Peak area has been an active place in the 'fight' against deforestation on the Freetown Peninsula. As early as the 1790s, the colony's botanist Adam Afzelius, strongly recommended that the trees on the slope be preserved (C. Fyfe 1962, A. Afzelius 1961 [1794-5]), while later colonial commentators expressed their disgust at the deforestation taking place on the hills (cf. J. Wilson 1858; R. Clarke 1863). In contemporary times, the area around the Peak, now covered in urban structures, has been the focal point of national treeplanting days. The current Vice President attended the most recent one in 2008, declaring the importance of

2 Commercial-logging had began in the region in 1816 (see C. Fyfe 1964:173), yet most activity had-been focused on the rivers-outside of the colony due to accessibility problems that the peninsula mountains posed (J. Alie 1990; D. Doward and A. Payne 1975) 
reforesting the area and eliminating 'illegal' structures. Although, as one government official cynically noted, his actions seem highly hypocritical considering that he is building his new house around the corner at the base of Leicester Peak (Interview, June 2008). There is thus a blurring between solutions and blame, with the Vice President constructing himself as part of the solution for deforestation, while others blame him for being implicit in its cause.

The Peninsula forest was declared a reserve in 1916 (see FD/SL 1917). In the lead up to the declaration, reserve boundaries had been drafted and a Reserve Resettlement Commission established to evict communities that were living within this designated boundary (see FD/SL 1913, 1916). These solutions are reminiscent of Roderick Neumann's (1998) notion of "imposing wilderness", which involves the manufacturing of a supposedly non-human natural landscape (also see R. Guha and J. Martinez-Alier 1997). A couple of small settlements (Hill Station and Regent) in the mountains were excluded from these evictions, based on Unwin's early recommendations (1909). This is unsurprising considering they housed the majority of the European population (see M. Gleave 1997). After the reserve's establishment, the Forestry Department paid limited attention to its management, focusing its activities instead on the Protectorate's resources (see-FD/SL 1922, 1929-1940); although the government did tighten its restrictions on the Peninsula forest reserve during World War II due to fears of fuelwood shortages (FD/SL 1941; R. Cline-Cole 1987, 1993). Furthermore, in 1972, the area was designated as a non-hunting reserve with the creation of the Wildlife Conservation Act.

Post-independence, Sierra Leone suffered a long period of corrupt authoritarian rule. Opposition to the central government was gradually eliminated, culminating in the declaration of Sierra Leone as a oneparty state in 1978 (A. Abraham 1993). Governance was administered through a system of acute patrimonialism, whereby necessary societal elements were kept appeased with strategic favours and payments (M. Bøas 2001; P. Richards 1996). A shadow state emerged, revolving predominantly around Sierra Leone's rich mineral resources, with only a small elite minority substantially profiting from them (W. Reno 1995; S. Kpundeh 1995). The central government focused its power and activities in Freetown, widely neglecting the rest of the country (see J. Riddell 1985, 2005a, 2005b), which led to an increase in rural-tourban migration that was not met with any strategic planning policies (J. Doherty 1985). Combined with an economic downturn, this increasingly impacted on Freetown, causing the city's expansion to be haphazard, resulting in many seeking residence in the sanctity of the forested peninsula mountains which contained potential livelihood resources (M. Harvey and J. Dewdey 1968; A. Millington 1985; R. Cline-Cole 1987).

The rapid change in Freetown's structure and population became even more acute with the outbreak of civil war in 1991 (W. Farmer 2004). Until 1997, Freetown was relatively insulated from the excesses of the conflict and was generally seen as a safe haven receiving vast numbers of people displaced by the war. Some authors estimating that Freetown's population trebled during the conflict (see I. Abdullah 2002; K. Boadi et al 2005). A substantial proportion of this population influx settled on Freetown's urban fringe, with livelihood opportunities left precarious by the war they subsequently had to rely on Freetown's surrounding forests for subsistence (Lebbie and Guries 2002; Hoffman 2007). During the war, the rebels thought of themselves as bush revolutionaries fighting against the elite of Freetown and symbolically threatened to utilise the peninsula forests as a base from which to attack the city. Citizens, as a result, became cautious and wary of their surrounding forest (see RUF/SL 1995; P. Richards 1996, 2001). Rebel incursions into Freetown did eventually occur; first by invitation of a recently coup d'état installed government (1997) and later by direct attack (1999), which were marked with widespread looting and the destruction of numerous buildings. These incursions displaced a significant proportion of Freetown's urban population, with many also relocating to forested urban fringe in a quest for safety (GoSL 2007). Any deforestation during periods of war is certainly not 'blamed' on the poor as such, and the peninsula forests occupied a complex position, perceived as both threat and haven. The war was finally brought to an end in 2001, with the final intervention of the British troops and subsequent successful peace negotiations.

The colonial and post-colonial contexts discussed here have played a substantial role in shaping contemporary approaches to deforestation on the Peninsula as well as subsequent prescribed solutions. The Peninsula forest remained a constant, while the meaning people prescribed to it varied and fluctuated. It was constructed as a place to be protected, as a source of livelihood and even as a place of danger throughout the war. The colonial period manufactured the Western Area Peninsula Forest Reserve, subsequently creating a dominant vision of how the forests should be maintained through the preservation of nature. This prompted a discourse of centralised control over natural resources that still remains in Freetown's contemporary governance structure. The post-colonial period saw the dramatic growth and change to urban Freetown as it spread rapidly and visibly into its surrounding forests. This rapid expansion has continued into the post-war era, although there has been an increasing demographic change in the urban fringe migrants, with wealthy abodes now being erected along the peninsula coast and more prominently up in the Leicester Peak Reserve area adjacent to the city. This unchecked urban encroachment was identified as a key issue driving deforestation by all of the research participants from both governmental and non-governmental backgrounds. Urban encroachment has also been documented as the main driver of deforestation in a variety of satellite imagery maps (see UNEP 2008). 


\section{Policy and project actors: government bodies and NGOs}

A key element in understanding the nuances of this 'wealthy' urban encroachment lies in the political contestations that have occurred across two key government ministries and between the two major political parties. Environment related issues in Sierra Leone are spread across the Ministry of Lands, Housing, Country Planning and the Environment (hereafter Ministry of Lands) and the Ministry of Agriculture, Forestry and Food Security (MAFFS). The conflation of responsibilities across these ministries has resulted in a contestation of land management jurisdictions on the Freetown Peninsula. Land on many parts of forest reserve, near Freetown's urban fringe, is of considerable financial value and reportedly a number of individuals in the Ministry of Lands have substantially profited by illegally allocating this land for sale (Concord Times 2002; Global Witness 2008; Standard Times 2008; various interviews in June 2008). The Forestry Commission (in MAFFS) has consistently complained about these jurisdictional intrusions but has generally lacked the power to intercede. The debate is highly public and was openly discussed by almost all interview respondents, both government and non-government. For example:

These two ministries seem to be at logger-heads at some point. Forestry wants to preserve the forest, Ministry of Lands gives out land to urban dwellers. (Interview with Government Representative; June 2008)

And similarly;

While the Ministry of Agriculture [MAFFS] wants to protect the forest, [...] the Lands Ministry is busy selling it. (Interview with NGO Representative June 2008)

Raymond Bryant and Sinead Bailey (1997) note that this kind of bureaucratic conflict is common, with resource-focused departments tending to hold more political strength than their environmental counterparts. Nevertheless, we should be cautious in viewing the Forestry Commission as the benign or weaker entity in this contestation, as many NGO representatives have alleged that it has been profiteering from the over-selling of logging licenses and receiving kickbacks from the 'illegal' charcoal trade (Various Interviews June \& July 2008; also see C. Squire 2001). As one NGO representative lamented:

Historically these bodies [Ministry of Lands and MAFFS] have not been working in the interest of the forests. If anything, it has been everything but the interests of the forest.

(Interview June 2008)

The debacle between these two Ministries came to the fore in 2005, when the Government party in power, through pressure from the NGO community, established a National Commission for Environment and Forestry (NaCEF) under the Vice President's office, which assumed control over 'environment' and 'forestry' issues from the two ministries. The purpose of this commission, as is evident by the title, was to address the country's environment and forestry issues, yet its establishment was ultimately politicised, as the President never sought the parliament's approval for its creation causing much ire among the political opposition:

NaCEF is not a legal institution as far as I am concerned...It was just a mere pronouncement made by [President] Kabbah. (Government Representative, Interview June 2008)

This greatly undermined NaCEF's mandate, and when the opposition regained power in 2007, 'environment' and 'forestry' were subsequently moved back to their respective ministries. NaCEF initially was maintained as a government institution, although it was stripped of its institutional power and funds until it was finally terminated in July 2008. After this, the World Bank indefinitely suspended funds for a planned Protected Area Management Project with NaCEF that had a focus on increasing protection for Peninsula forest as well as other forested areas in Sierra Leone (Interview June 2008). The current government is supposedly creating an Environmental Protection Agency in the near future, as NaCEF's replacement. Adding to the reforms, the new government also dismissed a major part of the bureaucracy, replacing it with much of its own party's stalwarts. Such political wrangling has occurred between the two major political parties since independence, and one NGO representative noted it has held back progress in the mitigation of deforestation (Interview July 2008).

There are a number of environmental NGOs based in Freetown involved in conservation projects along the Peninsula. Most were established throughout late 1980s and early 1990s and actively lobby the government with environmental concerns. Most are voicing their concerns about the Peninsula's decreasing forest cover. During 1990s these organisations established a Peninsula Action Group for the Environment to try and address the increasing encroachment and deforestation of the forest reserve, but the activities were largely negated due to instabilities caused by the war and coup d'états in Freetown. After the war these organisations re-enacted activities to address deforestation on the Peninsula, focusing on awareness-raising, tree-planting and research projects (cf. E. Sesay 2005; Birdlife nd). These activities have tended to focus on the rural communities living around the southern area of the Peninsula, rather than areas adjacent to the urban encroachment (this rural focus is discussed in depth in section 5 below). In 2004 a number of these environmental organisations formed an alliance under an umbrella organisation called the Environmental Forum for Action (ENFORAC) in attempt to give environmental issues a greater voice in Sierra Leone (see E. Wilkins 2006). 
Some tension ultimately exists between the NGO community and government bodies, as NGOs (supposedly less susceptible to corruption) tend to have a greater ability to sequester international funding, while the government bodies hold official jurisdiction of managing environmental problems. Therefore the government bodies often criticise the NGOs due to what they see as the hoarding of funding, while the NGOs criticise the government due to what they see as a lack of action (Interview July 2008; and personal observations). These NGOs rely predominantly on funding from large international environmental NGOs (i.e. The World Conservation Union, Conservation International) and bilateral funders (i.e. European Commission (EC), DfID), meaning that their agendas are often constricted to the preferences of external agents. As one NGO respondent noted:

[T] here is not much funding for projects in the Freetown area [which] has meant that a lot of our work has focused outside of the Western Area Peninsula Forest. (Interview June 2008)

This has meant that past projects have been strongly influenced by donor preferences. International environmental NGOs have tended to prioritise funding for the protection of forest reserves in upland Sierra Leone, as they are considered to be more pristine and to have a preserved biodiversity less impacted by humans. Bilateral donors, meanwhile, have preferred to fund projects that relate closely to main tenets of development discourse. While the Freetown peninsula forest relates to agendas of both types of donors, it is central to neither, and so it has tended to fall through the cracks.

It is also to important to recognise the role of the peninsula forests in this dialectic. Nature is too often viewed as a platform upon which human actors perform, a perspective that ignores that nature can have great agency in influencing societal outcomes. It is the deforestation on slopes surrounding Freetown that has galvanised NGOs into their actions. An increase in landslides, flooding and water shortages affecting Freetown is being increasing linked to the destruction of the forests and this has subsequently placed greater pressure on government bodies to address deforestation (see Concord Times 2001, 2006a, 2006b, 2007; Agence France Presse 2005, 2006; The Independent 2005; Standard Times 2005; D. Jabati 2005; S. Atere-Roberts 2006). The forest has been, and remains, a dynamic influence on the Freetown peninsula with these ecological hazards are just some example of the agency that the forest possesses. The forest continues to provide hazard protection for many, while many groups directly derive a livelihood from its resources and even some government actors are profiting by illegally selling its produce. To a certain extent, therefore, the forest needs to be also understood as actor that has a role in shaping social and political outcomes.

This argument emerges in other political ecology studies that show how politics is inevitably ecological, and ecology is inherently political (P. Robbins 2004). The material and discursive interaction between different government ministries and different political parties ultimately manifests corrupt and opportunistic approaches to the perception and management of environmental issues. Deforestation represents an environmental issue that is recognised by a variety of different governmental actors, but any solutions to any agreed issue are ultimately realised through a myriad of power struggles, operating in the context of bureaucratic corruption and political opportunism. NGOs active in trying to prevent deforestation on the peninsula need to negotiate complicated relations with both government bodies and international donors, which subsequently constrains their interventions. It is within this complex structural social reality that popularised policy solutions for deforestation are ultimately introduced.

\section{Tropical deforestation discourses}

The understanding of 'what deforestation is'; 'how and where it is occurring' and ultimately 'how it is to be addressed' is heavily contested. Taken alone 'to deforest' is non-agentive, simply meaning the removal of vegetation without reference to cause or reason. This implies simply the transformation of an ecological space, which contrasts markedly with the popularised understandings of deforestation. For example, these are the answers to "what is deforestation?" proffered by two Sierra Leonean Government officials:

[Deforestation is] when the forest cover [is] depleted [due to the] cutting down of trees for

burning of charcoal, or firewood or for farming programs. (Interview June 2008).

[Deforestation] means in simple terms just the clearing of the forests to meet, you know, our human desires [...] that means to say for farming, for charcoal, for fuelwood. (Interview June 2008).

The responses move beyond the simple 'what' of deforestation to the 'how'. There is recognition that the term does not just represent a physical occurrence, but is also an emotive notion that evokes a complexity of images and understandings. The Government officials' responses assert blame for deforestation lies with the activities of the poor rural populations. This resembles what Fairhead and Leach (1996a) describe as the 'dominant view of deforestation', which they claim has been popularised by global understandings of the phenomena. One of the consequences of this is that much environmental policy has been driven through powerful and popularised images of environmental change (M. Leach and R. Mearns 1996). A distinct gap is therefore created, between the environmental problems themselves and the policies promoted to address them. 
Adger et al. (2001) link this dominant view of deforestation to a broader global environmental management discourse, which has predominantly emerged from environmentalists and scientists in the developed world, who are concerned about global tropical deforestation rates (see also W. Adams 2001). This discourse has its roots in colonial environmentalism (see R. Grove 1995, 1997), such as that promoted by the early Sierra Leonean foresters Unwin and Lane-Poole. It perceives local methods of shifting cultivation, combined with a Malthusian understanding of population growth, as the greatest threats to nature (M. Leach et al. 1999; M. Leach and J. Fairhead 2000a). The poor, rural population are constructed as the ignorant agents of deforestation, while in contrast, scientists, aid bureaucrats and other experts are deemed to hold the capacity and knowledge on how nature works, and thus how deforestation is occurring and should be addressed (W. Adams 2003).

The presence of this discourse was prevalent among both government and NGO respondents in Freetown, with many offering a vague notion of 'poverty' as the major cause of deforestation on the Peninsula, with poverty deemed to be synonymous with environmental ignorance:

I believe that the government should educate the local people, the rural people, about how to manage their nature sustainably. (Interview with NGO representative June 2008)

This notion was frequently contracted by the respondents into the developmental idiom of 'sensitise'. This contains underlying presumptions of knowledge and power - "we need to sensitise people" (Interview June 2008) - that includes the premise that the respondent holds the key to understanding the dialectics of deforestation and the need to transfer this knowledge to the wider population - "we need to sensitise the general mass" (Interview June 2008). Inherent in this is a notion of not only the idea of superior knowledge, but also 'the right kind of knowledge'. There is an assumption that the 'sensitizer' has already been through a period of sensitisation; enlightenment about deforestation, which appears to be influenced by an external context:

[Sierra Leonean forestry] professionals, are being trained abroad, they have the principles, the methodologies, everything at their finger tips. (Interview with Government Representative

June 2008)

This assertion implies that the solution to the problem of Sierra Leone's deforestation lies in overseas expertise gained through training. It reflects the unequal power relations among nations in conceptualising environmental problems (R. Bryant and S. Bailey 1997), with solutions derived from overseas being given greater legitimacy. International environmental agendas tend to prioritise 'green' environmental issues such as climate change and biodiversity preservation, while 'browner' environmental health issues, which are more prevalent in the 'developing' world, ultimately receive less concern (G. McGranahan and D. Satterthwaite 2000). As McGranahan et al note, (1999:108) although broad environmental conceptualisations claim to incorporate the poor into their understandings, the process ultimately marginalises them. Sensitisation is not a two-way transfer of knowledge, rather it employs an externalised idea of deforestation that is imposed on development subjects.

In this understanding, blame for deforestation is ultimately attached to poverty and its supposed breeding of ignorance, which is purportedly demonstrated in the destructive daily practices of poor people. The respondents, through their knowledge, construct what they perceive to be a complete picture of deforestation, rationalising its causes and potential solutions. Peter Morriss suggests that such an externalisation of blame on the poor reflects a negative context of power. The actors are able to emphasise inability rather than disinclination in addressing the problem of deforestation and thus are able to absolve personal blame by claiming a lack of power (P. Morriss 2002). Moreover, by claiming to be in the process of 'sensitising' the poor, these elite actors, such as Government officials and NGO representatives, are therefore able to place themselves within the solution of deforestation. Their discourses are therefore traduced into acts of sensitisation.

Blaming poverty for the deforestation on the Freetown Peninsula is no doubt highly questionable. Deforestation issues on the Peninsula are not situated in the poor, rural context, where popular discourses presume it, rather it transcends urban, peri-urban and rural areas. All respondents recognised that urban encroachment is one of the greatest threats, a notion that is confirmed by satellite evidence (see UNEP 2008), yet the majority still stretched their accusations to include a rural notion of poverty. One Government representative noted the contradictory nature of her colleagues' perceptions:

They sometimes complain about poverty, but of course there are some areas where you have large clearing for the construction of houses. That is not poor people doing it. (Interview June 2008)

Sharachchandra Lélé suggests that such blaming of the poor is an intrinsic part of the development process. One that ultimately rationalises and hence legitimises the view that current development policies can (and should) continue unabated (S. Lélé 1991). Constructing the rural poor as the necessary agents to change, naturally feeds into the broader discourses of development and tropical deforestation. This goes beyond existence of a conceptual discourse, with development notions such as 'sensitisation' ultimately realised through definitive structures and processes. 


\section{The Power of Development}

In post-war Sierra Leone, the international agenda has gradually shifted from emergency relief to development interventions; described in aid vernacular as linking relief, rehabilitation and development (LRRD). This discourse of development is not experienced as an unstructured, abstract process, but rather it was realised through a very specific set of institutions, practices, and social relationships (S. Pigg 1992 cited in T. Perreault 2003). This is visibly evident in the landscape of Sierra Leone, with donor and aid agency offices, vehicles and staff featuring prominently in the setting of Freetown, while conspicuous signboards across the country demark previous projects and current development activities. More subtle is the emergence of a development lexicon, which utilises strategic buzzwords such as 'participation', 'empowerment', and 'poverty reduction'. Andrea Cornwall and Karen Brock argue that these buzzwords frequently get drained of their politics and power to be reconfigured as an apolitical language that all can agree on (A. Cornwall and K. Brock 2005; see also R. Jeffrey and B. Vira 2001). This development lexicon is nevertheless powerful, as it tends to be requisite in project proposals and donor reports, constricting the way in which problems can be discussed.

The destruction of governance structures and infrastructure during the war has meant that these development activities have largely been driven by external funding and expertise (B. Baker and R. May 2004). Environmental issues have generally been given low priority and little funding in Government departments, which has ultimately undermined their ability to implement policies and projects (Interview June 2008). As noted earlier, local NGOs in Sierra Leone are almost entirely reliant on international donor funding, meaning that their survival relies on interacting with external actors, who subsequently wield a great amount of influence over the NGOs activities (A. Hudock 1995). This funding is generally obtained through a system of written proposals, which are required to be focused within in the donor agencies' assigned criteria. Funding for environmental NGOs in Freetown has tended to be directed towards projects without direct budget support and limited administrative allowances, which consequently limits the possibility of more localised collective action (S. Willans 2008). Through such mechanisms development ultimately creates a conceptual space that constrains the manner in which problems can be described or even imagined.

A form of 'development professionalism' has ultimately evolved in which individuals are often employed for their proficiency in proposal writing, rather than their direct skills or knowledge of relevant issues. A trenchant example of this is the approval by the European Commission (EC) in August 2008 for a three million Euro (US\$4.2 million) project to improve conservation across the Western Area Peninsula Reserve (see A. Kabia 2008). The project proposal was administered by a European NGO based in Sierra Leone and a self-reported 'participatory' bottom-up approach to environmental management. However, it was crafted by a consultant flown in from Europe for two weeks in June 2008, who had a background in the related area of hydrology but no previous experience specific to Sierra Leone.

This is common scenario. The NGO's local office recognised that bringing in an international consultant to write the proposal rather than a local partner was problematic, but the decision was made by its head office in Europe. This decision was justified in that the proposal was funded against heavy completion from other proposed projects around the world; but this nonetheless brings into question the rigor in which the proposed project was constructed. Due to the time-frame imposed on the consultant, it was necessary for them to compose the proposal from fly-by visits of different government offices and local environmental NGOs; supposedly 'equal partners' in the project. Of the communities along the Peninsula who were designated as the direct beneficiaries of the planned project, none were visited. The NGO ultimately decided to focus its intervention on the southern 'rural' half of the peninsula, an area with much less deforestation (see Figure 2), due to the issue of urban encroachment being seen as overtly political and complicated; meaning that such a project is liable to have greater impact if focused in rural areas.

This highlights one of the main complications that has developed in regards to addressing deforestation on the peninsula. While NGOs and foreign organisations have long been populating the forested northern fringe of Freetown, it is only recently that the same organisations have been mandated to protect that forest. The European Commission's (EC) head office is one of the participants in the largest single forest encroachment, and so its ability to make unbiased judgments and funding decisions is severely limited. By manipulating the location of the intervention in this case, the NGO was able to reconfigure the issue of deforestation on the Peninsula as a rural one; making intervention less politically complicated and ultimately sitting more comfortably with both EC's globalised understandings of deforestation (see EC 2007-8) and the developmental intervention context. Crucial here is the decision as to who needs to be 'sensitised.' While the EC may be playing a role in driving the deforestation, it is not a development 'subject' and therefore cannot easily be conceptualised as part of the problem. Development relies on setting up the world as a picture (A. Escobar 1995), one that is ultimately imposed on, and contorted onto, local contexts. 


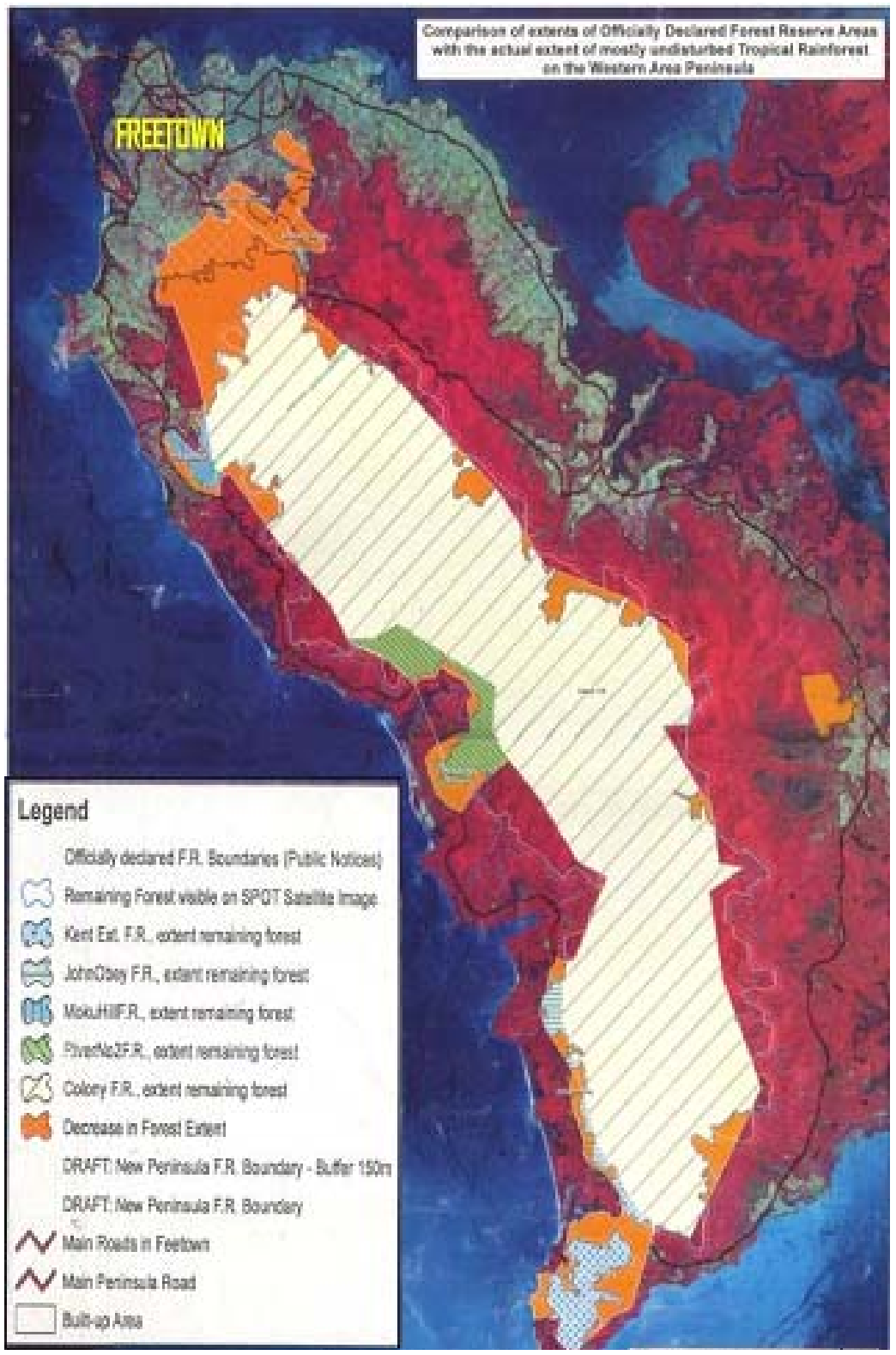

Fig. 2: Satellite map of deforestation on the Freetown Peninsula, titled "Comparison of extent of officially declared Forest Reserve Areas and the actual extent of mostly undisturbed tropical rainforest on the Western Area Peninsula". The orange on the map, "Decrease in forest extent" indicates where the bulk of deforestation is occurring in the area. Source: Development Assistance Coordination Office (DACO) in Freetown, created by the United Nations Development Programme (UNDP).

The 'professionalization' of development is pervasive in this instance. While the ability to direct funds into any environmental initiative is commendable, it also reflects how external actors, through the process of development, can exert an overly significant level of influence in defining the issue of deforestation on the peninsula. Foreign organisations, like Lane-Poole, Unwin and the colonial government nearly a century earlier, do hold a substantial amount of power in setting future policy and project agendas for the future of the Western Area Peninsula Reserve. Such an imbalance in power between local and international is an actuality of the development world (F. Manji 2000) and often causes a situation whereby local environmental NGOs are chasing (conditional) donor money, rather than having the freedom or power 
to conceptualise their own individual responses to environmental problems. This represents a typology of power that Steven Lukes (2004) describes as coercion; whereby international agendas can be set at the local level indirectly due to control over ideas and capital. Thus a moral agenda for deforestation issues is being highly influenced by external agents and ideas (R. Bryant 2005).

Government agencies and local NGOs are unlikely to oppose such a proposal, even if they disagree on its deontological construction, as it represents an opportunity to garner funding for the Western Area Peninsula Reserve, and to a lesser extent, for their respective departments and organisations. Other projects addressing deforestation on the peninsula by local NGOs contain a similar focus on 'the rural' in the context of poverty. Funding has been successfully obtained for projects focusing on tree planting (various interviews, June 2008) and awareness campaigns focused on the impacts of rural activities (timber harvesting and coal burning) (E. Sesay 2005; E. Wilkins 2006; EFA 2007). Efforts to address urban encroachment, however, have relied mainly on unfunded lobbying and advocacy campaigns (various interviews, June 2008). Thus, the international development agenda in Sierra Leone, through its control of funds and to an extent its ideas, has constructed an emphasis on preventing deforestation on the Freetown Peninsula through a rural context. This is based more on popularised perception and convenience of intervention than local realities, which has meant that local NGOs risk becoming service providers for external agencies, rather than being able to conceptualise problems on their own terms. Power and knowledge are central to this process, which has been epitomised in the development idiom as 'sensitisation', the imposition of external perceptions for local solutions.

\section{The Construction of Solutions}

In examining the power of global deforestation ideas and the development context it is important not to lose sight of the influence of local influences. This includes certain political, social and environmental realities, such as bureaucratic corruption, political opportunism and the actuality of deforestation itself. Development is an influential force, but not a homogenous one. While development activities addressing deforestation have tended to focus on the rural section of the peninsula due to a convenience of perception, this does not eliminate the environmental and political reality of Freetown's urban encroachment and its impact on the surrounding forests. Concerns over deforestation in Freetown have not just risen from abstract dominant discourses, but also have evolved from more localised discourses, perceptions and actions.

As noted in section three, an increase in the number of hazards in Freetown has progressively been linked to deforestation on the Peninsula Mountains. The influence of this increasing rhetoric seems to have resonated to the highest offices. When heavy winds hit Freetown in May 2008, causing widespread damage, urban encroachment and deforestation were blamed and condemned by the President and Freetown's Mayor (see The Exclusive 2008; H. Williams 2008). In response, the President subsequently mandated the Ministry of Lands to enact a housing demolition campaign to address the issues of urban encroachment (Interview June 2008; S. Rogers 2008).

Housing demolition campaigns described in Krio, the country's lingua franca, as broke ose exercises, are not new to the Sierra Leone political landscape, first being enacted on a large scale a few years earlier by the previous Government in power (see Concord Times 2006c). On that occasion they reached a dramatic climax in mid-2006 when Kenneth Moore, the Ministry's representative in charge of demolitions, was abducted in the field during a broke ose exercise by an angry mob. His corpse was found two days later at the base of Leicester Peak next the newly built United States Embassy (see P. Beckley 2006; J. Mansaray 2006). A major complication of these demolitions is that they have been placed under the Ministry of Lands, the same Ministry that has reportedly been illegally selling land to many wealthier encroachers. It has also been noted that other wealthier encroachers have been able to exploit informal networks to acquire legal documentation through the Ministry to legitimise their land claims (I. Abdullah 2002). This corruption and socio-economic influence has meant that the notion of 'illegal' and 'legal' housing ultimately becomes convoluted. As one NGO respondent noted:

He [the President] has given the mandate to the Lands Ministry to demolish the houses that are being erected there [Leicester Peak Area], the illegal structures that are being erected there, but how can we tell which are the legal or illegal structures. Because if you are talking about legal structures, then erectors of legal structures are right in the place where they are not suppose to be doing it. So if you are only looking for illegal structures then the development [encroachment] will continue. (Interview June 2008)

The poor do not have socio-economic tools at their disposal to exploit these informal and corrupt networks to 'legitimise' their land claims. This has meant that their pan bodies ${ }^{3}$ have tended to be physically targeted and destroyed during these broke ose campaigns. Blame for deforestation, in this context, is therefore being applied to the poor once again:

3 A Krio word to describe simple lean-to buildings, usually made out of zinc, that are mainly utilised by Freetown's poorer residents.

Journal of Political Ecology

Vol. 16, 2009 
Some of them when they came they just grabbed the land, you know, occupied the land, without even coming to the Ministry of Lands, Right to build...they just squat there, squatters, we have a lot of pan bodies! (Ministry of Lands Official, Interview June 2008)

Development discourses may prioritise rural interventions in addressing the issue of deforestation on the Freetown Peninsula, yet this has not eliminated the issue of urban encroachment. The Sierra Leone government is under pressure to address the issue and has acted, but their implementation is ultimately filtered through a system of bureaucratic corruption and political opportunism. The end result is a similar mimicking of the development discourse, which constructs the poor as the main perpetrators of forest destruction. Though these constructions differ somewhat, the 'rural' poor are constructed as benign yet ignorant degraders, in need of sensitization and enlightenment from elite officials in Freetown, while the urban encroachers are lambasted as malign 'land grabbers' and are dealt with through somewhat draconian demolition campaigns.

These 'blame the poor' discourses ultimately stand in contrast with deforestation occurrences on the peninsula. The Ministry of Land's targets the demolition of pan bodies, while conveniently sidestepping the issue of wealthier urban encroachers, which is alleged to include the EC's head office and the US Embassy. The Ministry has therefore been able to construct a solution that can exist alongside its corrupt process of allocating lands 'illegally' to those who can afford to pay. Development interventions focus on reforming the 'rural' poor, while ignoring more complex structural causes of deforestation. Ignoring urban encroachment is an obvious one, but there is also a whole political economy of consumption in Freetown that utilises timber from the Peninsula for activities such as construction and cooking. There is an extensive commodity chain that transports fuelwood, charcoal and building timber from the peninsula forests to the households of Freetown (W. Farmer 2004; P. Richards 1996). Yet this 'blame the poor' perception sits more conveniently in development's broader discourse. It was reflected overtly in a response from a United Nations Development Programme (UNDP) representative involved in financing a project, titled: "The Fuelwood Project of Youth Empowerment and Sustainable Management of the Western Area Peninsula Forest." After declaring that deforestation was one of the greatest threats to Freetown due to its adverse impacts on the city's water supply, he calmly noted when challenged about the issue of urban encroachment by wealthy residents:

I am not against urban encroachment into the forest as it is providing jobs for the youth of

Sierra Leone. (Interview, June 2008)

Thus the official's perception of the deforestation problem can be understood as an issue of convenience and demonstrates the extent to which labour force participation and economic growth take precedence over ecology in dominant development discourse. This UNDP funded project is focusing on tree planting across the peninsula, which fits neatly into popularised understanding of how to address deforestation. Local NGOs that have been involved in the implementation of the project have complained of being hindered by the slow release of funds, while the very limited amount of tree planting was forced to be on private sites, rather than the forest reserve, after the UNDP's failure to include the Forestry Division in the initial conception of the project (various interviews, June \& July 2008). As one respondent noted, despite these major project shortcomings, this did not stop the UNDP from sending a fleet of UN vehicles to take pictures of the tree planting sites and celebrate the projects ongoing 'success' (Interview, July 2008), supporting the wider discourses that such interventions should be the primary means of addressing deforestation.

\section{Conclusion}

Deforestation concerns by urban-centric actors surrounding the Freetown Peninsula's forests have existed since the earliest settlement of Freetown, becoming more formalised in the early part of the $20^{\text {th }}$ century when the British Colonial Government established a Forestry Department and the Western Area Peninsula Reserve. The rapid growth of Freetown in subsequent years, shaped by authoritarian rule and a ten-year civil war, has focused deforestation issues on the Peninsula. The city's urban fringes have rapidly pushed into the forested mountains, leading to a contemporary scenario of contestation over deforestation, both materially and discursively, that is shaped by the local context and by external entities.

Evolving from this colonial past has also been a strong tendency towards blaming poverty, and the poor, for the Freetown Peninsula's perceived deforestation woes. The urban poor are consistently constructed as the agents of deforestation, while direct interventions into their activities are constructed for its solution. The rural poor are conceptualised through development discourses as being in need of "sensitisation," to be reformed from development interventions and projects by implementers that supposedly hold an enlightened understanding of deforestation and environmental issues. The heavy reliance on donor funds for local projects has ultimately ensured this conception remains dominant. Nevertheless, these conceptions do not eliminate the reality of urban encroachment and the public pressure applied to the government to address it. The government's response, filtered through bureaucratic corruption and political opportunism, is to focus on socio-economically weak demographic of the urban poor, relying on punitive demolition measures as a solution. Solutions have subsequently been delineated between rural 
and urban perspectives, but the role of power and knowledge has been consistent to both. Elite actors hold the power, and supposedly the subsequent knowledge to perceive and deal with deforestation issues.

Importantly, this research reveals how a study of 'urban elites' can help to understand the politics and power at play in creating policy and projects in an unequal world. Central to this has been the understanding that Government Departments, like NGOs, are not homogenous entities, despite their common presentation as such, but rather contain a disunity that has allowed varying conceptual spaces for blame to be constructed. This investigation has duly illustrated that deforestation on the Freetown Peninsula is not a product of poverty, as it is commonly portrayed, but rather is allowed to exist and grow in a context constrained and influenced by government corruption, urban planning issues and developmental discourses. Such a context has created a geography of intervention that aims to sensitize the rural poor and evict the urban poor. On the world's most rapidly urbanizing continent, the sensitize-to-blame ratio is set to continue increasing. The political ecology of deforestation presented here asserts that the causes of deforestation occur at different levels of government are influenced by different discourses, actions and actors across a broad political, social and economic spectrum. The benefit of post-structuralist insights helped to inform the role that perceptions and the construction of blame play in influencing outcomes. If deforestation issues on the Freetown Peninsula are to be addressed effectively, then there ultimately needs to be greater reflexivity among the 'elite actors' in Freetown that are mandated to address it. Environmental problems, such as deforestation, need to be examined beyond their proximate locations to include analysis of the complex milieu of actor interactions and influential discourses if they are to be understood and addressed adequately.

\section{References}

\section{Selected Interviews by the Author ${ }^{4}$}

Interview with NGO Representative, Environmental Forum for Action, June-July 2008, Freetown

Interview with NGO Representative, Green Scenery, June-July 2008, Freetown

Interview with NGO Representative, Environmental Foundation for Africa, June-July 2008, Freetown

Interview with NGO Representative, Conservation Society of Sierra Leone, June-July 2008, Freetown

Interview with NGO Representative, Beautification, Rehabilitation and Conservation Organisation, June-July 2008, Freetown

Interview with NGO Representative, Conservation Society of Sierra Leone, June-July 2008, Freetown

Interview with Government Representative, Freetown City Council, June-July 2008, Freetown

Interview with Government Representative, National Tourism Board of Sierra Leone, June-July 2008, Freetown

Interview with Government Representative, Ministry of Agriculture, Forestry and Food Security, June-July 2008, Freetown

Interview with Government Representative, Guma Valley Dam Water Company, June-July 2008, Freetown

Interview with NGO Representative, Environmental Foundation for Africa, June-July 2008, Freetown

Interview with UN Representative, United Nations Development Programme, June-July 2008, Freetown

Interview with Government Representative, Ministry of Lands, Housing, Country Planning and the Environment, June-July 2008, Freetown

Interview with Government Representative, National Commission for Environment and Forestry, June-July 2008, Freetown

Interview with Government Representative, Ministry of Agriculture, Forestry and Food Security, June-July 2008, Freetown

Interview with NGO Representative, Environmental Foundation for Africa, June-July 2008, Freetown

4 The names of the participants and specific dates of the interviews have not been displayed here to help ensure participant anonymity. 
Interview with Government Representative, Western Area Rural District Council, June-July 2008, Freetown

Interview with NGO Representative, Oxfam-UK, June-July 2008, Freetown

Interview with NGO Representative, Plan - Sierra Leone, June-July 2008, Freetown

Interview with Government Representative, Freetown City Council, June-July 2008, Freetown

Interview with Consultant, Sierra Leone Electricity Corporation, June-July 2008, Freetown

Interview with NGO Representative, Tacugama Chimpanzee Sanctuary, June-July 2008, Freetown

\section{Bibliography}

Abdullah, I.

2002. Space culture and agency in contemporary Freetown: The making and remaking of a postcolonial city. In Under siege: four African cities, Freetown, Johannesburg, Kinshasa, Lagos, eds. O. Enwezor, C. Basualdo, U. M. Bauer, S. Ghez, S. Maharaj, M. Nash and O. Zaya, 201-212. Germany: Hatje Cantz Publishers.

Abraham, A.

1993. Local government and the provision of social services in Sierra Leone. In The State and the provision of social services in Sierra Leone since Independence, 1961-1991, C. M. Fyle (ed.), Dakar: CODESRIA.

Adams, W. M.

2001. Green development: environment and sustainability in the third world, $2^{\text {nd }}$ Edition, London Routledge.

Adams, W. M.

2003. Nature and the colonial mind. In Decolonizing nature: strategies for conservation in a postcolonial era, eds. W. M. Adams and M. Mulligan, 16-50. London: Earthscan.

Adger, N. W., T. A. Benjaminsen, K. Brown, and H. Svarstad

2001. Advancing a political ecology of global environmental discourses. Development and Change 32: $681-715$.

Afzelius A.

1967 [1975-1796]. Sierra Leone Journal 1795-1796, ed. P. Alexander, Studia Ethnographia Upsaliensia, XXVII, Uppsala: Boktryckeri Aktiebolag.

Agence France Presse

2005. Seven dead after downpour loosens boulder in Sierra Leone. July 11.

Agence France Presse

2006. Sierra Leone capital hit by worst water shortages in decades. July 5.

Alie, J. A. D.

1990. A new history of Sierra Leone. London: MacMillan.

Atere-Roberts, $\mathrm{S}$.

2006. Analysis and recommendations for short and medium term solutions for Guma's problems. Engineering Report, September 7.

Baker, B. and R. May

2004. Reconstructing Sierra Leone. Commonwealth and Comparative Politics 42(1): 35-60.

Beckley, P. O.

2006. Kenneth Moore's death - a wake up call for action. Concord Times, June 30.

Birdlife

nd. Community development action in Sierra Leone: integrated conservation management and community development action for poverty alleviation, Western Area Peninsula Forest, Sierra Leone. Birdlife International (accessed from www.birdlife.org on June 6 2006).

Boadi, K., M. Kuitunen, K. Raheem and K. Hanninen

2005. Urbanisation without development: environmental and health implications in African Cities. Environment, Development and Sustainability 7: 465-500.

Bøas, M.

2001. Liberia and Sierra Leone - dead ringers? The logic of neopatrimonial rule. Third World Quarterly 22(5): 697-723. 
Bryant, R. L.

1997. The political ecology of forestry in Burma, 1824-1994. London: C. Hurst and Co. Publishers Ltd.

Bryant, R. L.

2005. Nongovernmental organisations in environmental struggles: politics and the making of moral capital in the Philippines. Yale University Press: New Haven.

Bryant, R. L. and S. Bailey

1997. Third world political ecology. London: Routledge.

Buxton, V. T. F.

1913. The Creole in West Africa. Journal of the Royal African Society 12(48): 385-394.

Clarke, R.

1863. Sketches of the colony of Sierra Leone and its inhabitants. Transactions of the Ethnological Society of London 2: 320-363.

Cline-Cole, R. A.

1987. The socio-ecology of firewood and charcoal on the Freetown Peninsula. Africa 57(4): 457-497.

Cline-Cole, R. A.

1993. Wartime forest energy policy and practice in British West Africa: social and economic impact on the labouring classes 1939-45. Africa 63(1): 56-79.

Concord Times

2001. Boulder kills 3-yr old boy, 4 others injured. July 16.

Concord Times

2002. The politics of selective punishment. July 1 .

Concord Times

2006a. Guma looses 19 million gallons of water daily, Andrew Kieli Says. August 2.

Concord Times

2006b. As Freetown continues to be deforested: Guma Valley to run out of water. June 13.

Concord Times

2006c. Lawlessness! 'Freetown is the worst,' Bobson Sesay Says. June 9.

Concord Times

2007. Kroo Bay residents work to rescue their community. September 7.

Cornwall, A. and K. Brock

2005. Beyond buzzwords: "poverty reduction", "participation" and "empowerment" in development policy. Overarching Concerns, Programme Paper Number 10, United Nations Research Institute for Social Development. http://tinyurl.com/mkhzpx

Crang, $\mathrm{M}$.

2002. Qualitative methods: the new orthodoxy? Progress in Human Geography 26(5): 647-655.

Doherty, J.

1985. Housing and development in Freetown, Sierra Leone. Cities: 2(2): 169-164.

Dorward, D.C. and Payne, A. I.

1975. Deforestation, the decline of the horse, and the spread of the tsetse fly and trypanosomiasis (nagana) in nineteenth century Sierra Leone. The Journal of African History 16(2): 239-256.

EC (European Commission)

2007-2008. Programme: Environment and Sustainable Management of Natural Resources, including energy. Grant Application Form. Contracting Authority: European Commission (EC), Restricted Call for Proposals.

EFA

2007. The Environment Foundation for Africa Annual Report 2006-7. The Environmental Foundation for Africa, Sierra Leone.

Escobar, A.

1995. Encountering development: the making and unmaking of the Third World. Princeton University Press. 
Escobar, A.

1996. Constructing nature: elements for a poststructural political ecology. In Liberation Ecologies: Environment, Development and Social Movements, eds. R. Peet and M. Watts, 46-68. London: Routledge.

Exclusive, The 2008. Winds in the Western Area. June 2.

Fairhead, J. and M. Leach 1993. Degrading people? The misuse of history in Guinea's environmental policy. Paper presented at African Studies Association meeting, Boston: December 2-6.

Fairhead, J. and M. Leach 1994. Contested forests: modern conservation and historical land use in Guinea's Ziama Reserve. African Affairs, 93: 481-512.

Fairhead, J. and M. Leach 1995a. False forest history complicit social analysis: rethinking some West African environmental narratives. World Development 23(6): 1023-1035.

Fairhead, J. and M. Leach 1995b. Reading forest history backwards: the interaction of policy and local land use in Guinea 1893-1993. Environment and History 1(1): 55-91.

Fairhead, J. and M. Leach 1996a. Misreading the African landscape: society and ecology in a forest-savanna mosaic. Cambridge: Cambridge University Press.

Fairhead, J. and M. Leach 1996b. Enriching the landscape: social history and the management of transition ecology in the forest-savanna mosaic (Republic of Guinea). Africa 66(1): 14-36.

Fairhead, J. and M. Leach

1996c. Rethinking the forest-savanna mosaic: colonial science and its relics in West Africa. In The lie of the land: challenging received wisdom on the African environment, eds. M. Leach and $\mathrm{R}$. Mearns, 105-121 Oxford: James Currey.

Fairhead, J. and M. Leach 1998a. Reframing deforestation: global analyses and local realities: studies in West Africa. Global Environmental Change Programme. London: Routledge.

Fairhead, J. and M. Leach 1998b. Reconsidering the extent of deforestation in the twentieth century West Africa. Unasylva 192(49): 38-46.

Fairhead, J. and M. Leach

2000a. Shaping socio-ecological and historical knowledge if deforestation in Sierra Leone, Liberia and Togo. In Contesting forestry in West Africa, eds. R. Cline-Cole and C. Madge, 64-95 Aldershot: Ashgate.

Fairhead, J. and M. Leach 2000b. Desiccation and domination: science and struggles over environment and development in colonial Guinea. The Journal of African History 41(1): 35-54.

Fairhead, J. and M. Leach

2002. Practising biodiversity: the articulation of international, national and local science. Policy in Guinea. IDS Bulletin 33(1): 102-110.

Fairhead, J. and M. Leach

2003. Science, society and power: environmental knowledge and policy in West Africa and the Caribbean, Cambridge: Cambridge University Press.

Farmer, W. L.

2004. Interface between the biophysical environment in informal settlements and poverty in developing countries: the case for Sierra Leone. PhD Thesis, Leicester: De Montfort University. FD/SL

1913. Report on the Forest Administration for the Year 1912. Forestry Department of Sierra Leone. London: Waterlow and Sons Limited 
$\mathrm{FD} / \mathrm{SL}$

1914-41. Annual Report of the Forestry Department, Forestry Department of Sierra Leone. Freetown: Government Printing Office

Forsyth, T.

2003. Critical political ecology: the politics of environmental science. London: Routledge.

Fyfe, C.

1962. A history of Sierra Leone. Oxford: Oxford University Press.

Fyfe, C.

1964. Sierra Leone inheritance. London: Oxford University Press.

Gleave, M. B.

1997. Port activities and the spatial structure of cities: the case of Freetown, Sierra Leone. Journal of Transport Geography 5(4): 257-275.

Global Witness

2008. Sierra Leone: power struggle and illegal logging threaten remaining forests. Press Release, $29^{\text {th }}$ of January.

GoSL

2007. The National Action Programme to Combat Desertification/Land Degradation (UNCCD) of Sierra Leone (Draft Copy).

Grove, R. H.

1995. Green imperialism: colonial expansion, tropical island edens and the origins of environmentalism, 1600-1860. Cambridge University Press.

Grove, R. H.

1997. Ecology, climate and empire: colonialism and global environmental history: 1400-1940, London: The White Horse Press.

Guha, R. and J. Martinez-Alier

1997. Varieties of environmentalism: essays North and South. London: Earthscan.

Harvey, M. and J. Dewdney

1968. Planning problems in Freetown. In Freetown: A Symposium, eds. C. Fyfe and E. Jones, 179182. Freetown: Sierra Leone University Press.

Hoffman, D.

2007. The Disappeared: images of the environment at Freetown's urban margins. Visual Studies 22(2): $104-119$.

Hudock, A. C.

1995. Sustaining Southern NGOs in resource-dependent environments. Journal of International Development, 7(4): 653-667.

Ickowitz, A.

2006. Shifting cultivation and deforestation in tropical Africa: Critical Reflections. Development and Change 37(3): 599-626.

Independent, The

2005. Illegal construction of houses endangers lives. July 25.

Jabati, D. A.

2005. The rain, the water, the drainages and the city dwellers. Awareness Times, July 12.

Jeffrey, R. and B. Vira (eds.)

2001. Conflict and cooperation in participatory natural resource management. Hampshire: Palgrave.

Kabia, A. K.

2008. EU poised to conserve Western Peninsular Forest Reserve in Sierra Leone. Awareness Times December 12.

Kpundeh, S. J.

1995. Politics and corruption in Africa: a case study of Sierra Leone, Lanham: United Press of America.

Lane-Poole C. E.

1911. Report on the forest of Sierra Leone. London: Waterlow and Sons Limited. 
Leach, M. and J. Fairhead

2000a. Challenging neo-Malthusian deforestation analyses in West Africa's dynamic forest landscapes. Population and Development Review 26(1): 17-43.

Leach, M. and J. Fairhead

2000b. Fashioned forest pasts, occluded histories? International environmental analysis in West African locales. Development and Change 31(1): 35-59.

Leach, M. and J. Fairhead

2002. Changing perspectives on forests, science/policy processes in wider society. IDS Bulletin 33(11): $1-12$.

Leach, M. and R. Mearns (eds.)

1996. The lie of the land: challenging received wisdom on the African environment. African Issues, The International African Institute. London: James Currey.

Leach, M., R. Mearns and I. Scoones

1999. Environmental entitlements: dynamics and institutions in community-based natural resource management. World Development 27(2): 225-247.

Lebbie, A. R. and R. P. Guries

2002. The palm wine trade in Freetown, Sierra Leone: production, income and social construction. Economic Botany 56(3): 246-254.

Lélé, S. M.

1991. Sustainable development: a critical review. World Development 19(6): 607-621.

Lukes, S.

2004. Power: a radical view, $2^{\text {nd }}$ Edition, London: Palgrave MacMillan.

Manji, F.

2000. Collaboration with the South: agents of aid or solidarity?. In Development, NGOs and civil society, ed. J. Pearce, pp.75-79. Oxford: Oxfam publication.

Mansaray, J.

2006. Murder in Freetown, Sierra Leone as "Broke Ose" exercise turns deadly. Awareness Times June 10.

McGranahan, G. and D. Satterthwaite

2000. Environmental health or ecological sustainability? Reconciling the brown and green agendas in urban development. in Sustainable cities in developing countries: theory and practice at the millennium, ed. C. Pugh, 73-90. London: Earthscan.

McGranahan, G., J. Songsore and M. Kjellén

1999. Sustainability, poverty and urban environmental transitions. In The Earthscan reader in sustainable cities, ed. D. Satterthwaite, 107-130. London: Earthscan.

Millington, A.C.

1985. Soil management under urban-fringe farming systems in Freetown, Sierra Leone. Soil Use and Management 1(4): 110-112.

Millington, A. C.

1987. Environmental degradation, soil conservation and agricultural policies in Sierra Leone, 1895-

1984. In Conservation in Africa: people, policies and practice, eds. D. Anderson and R. H. Grove, 229-248. Cambridge University press.

Morriss, $\mathrm{P}$.

2002. Power: a philosophical analysis, $2^{\text {nd }}$ Edition. Manchester: Manchester University Press.

Neumann, R. P.

1998. Imposing wilderness: struggles over livelihood and nature preservation in Africa. Berkley: University of California Press.

Nyerges, A. E.

1994. Deforestation history and the ecology of swidden fallows in Sierra Leone. Boston. MA: Boston University, Working Paper 185.

Peet, R. and M.J. Watts (eds.)

1996. Liberation ecologies: environment, development and social movements, London: Routledge. 
Peet, R. and M.J. Watts (eds.)

2004. Liberation ecologies: environment, development and social movements, $2^{\text {nd }}$ Edition. London: Routledge.

Perreault, T. A.

2003. 'A people with our own identity': towards a cultural politics of development in Ecuadorian Amazonia. Environment and Planning D: Society and Space 21: 583-606.

Reno, W.

1995. Corruption and state politics in Sierra Leone. Cambridge: Cambridge University Press.

Richards, P.

1996. Fighting for the rain forest: war youth and resources in Sierra Leone. Oxford: James Currey.

Richards, P.

2001. Are "Forest" Wars in Africa resource conflicts? The case of Sierra Leone. In Violent Environments, eds. N. L. Peluso and M .Watts, 65-82. London: Cornell University Press.

Riddell, J. B.

1985. Beyond the geography of modernization: the state as a redistributive mechanism in independent Sierra Leone. Canadian Journal of African Studies / Revue Canadienne des Études Africaines 19(3): 529-545.

Riddell, J. B.

2005a. Sierra Leone: urban-elite bias, atrocity \& debt. Review of African Political Economy 32: 115 $-133$.

Riddell, J. B.

2005b. Urban bias, redistribution, and state collapse: the lessons of Sierra Leone. In West African worlds: paths through socio-economic change, livelihoods and development, eds. R. Cline-Cole and E. Robson, 109-128. Harlow: Pearson Education.

Robbins, P.

2004. Political ecology: a critical introduction. London: Blackwell.

Rogers, S.

2008. Broke ose to start soon. Awoko June 6.

RUF/SL

1995. Footpaths to democracy: towards a new Sierra Leone. Revolutionary United Front of Sierra Leone.

Sesay, E. M.

2005. Promoting conservation for the Western Area Peninsular Forest Reserve (WAPFR) in Sierra Leone. Final Report, The Environmental Foundation for Africa (EFA).

Sivaramakrishnam, K.

1999. Modern forests: statemaking and environmental change in colonial East India. California: Stanford University Press.

Squire, C. B.

2001. Sierra Leone's biodiversity and the civil war: a case study prepared for the Biodiversity Support Program. Washington DC: Biodiversity Support Program.

Standard Times

2005. Green scenery on land degradation. July 20

Standard Times

2008. Conspiracy! Corrupt officials exposed at Ministry of Lands Housing and the Environment. January 23.

UNEP

2008. Freetown, Sierra Leone. Atlas of our changing environment, United Nations Environment Program (accessed from www.na.unep.net August 8 2008).

Unwin, A. H.

1909. Report on the forestry problems in Sierra Leone. London: Waterlow and Sons.

Wilkins, E.

2006. Unity in Action Sierra Leone. CEPF News, (available from www.cepf.net). 
Williams, H. A. G.

2008. Press release by his Worship the Mayor (AG.) Councillor Herbert Akieremi George Williams, Following the wave of heavy winds and rain that hit Freetown Wednesday $28^{\text {th }}$ May, 2008. Press Release, Freetown City Council.

Willans, S. L. 2008. Civil society and donor funded democratisation: Sierra Leone case, Windsor: University of Windsor.

Wilson, J. L.

1856. Western Africa: its history, condition and prospects. London: Sampsons Low.

\begin{abstract}
This article examines the issue of deforestation on Sierra Leone's Freetown Peninsula, specifically analysing the gap that exists between the rhetoric surrounding the problem of deforestation and the subsequent policies and projects that are implemented to address it. It is argued in this paper that this gap can be better understood by examining how different actors involved in policy and projects interact over the issue of deforestation. Such an examination reveals how these actors produce discourses of blame towards poorer, politically weaker groups, which ultimately results in deforestation 'solutions' that intervene into their lives. These prescriptions of blame and subsequent solutions for deforestation are negotiated through a combination of local realities, which includes the occurrence of deforestation, and global influences such as development discourses and interventions. The analysis here reflects a political ecology framework that also draws from post-structuralist insights and reveals how underlying discourses, actions and actors across a broad political, social and economic spectrum ultimately play a role in influencing the causes, perceptions and solutions relating to deforestation.
\end{abstract}

Keywords: Deforestation, Political Ecology, Freetown, Discourses, Development, Sierra Leone, Africa

\title{
Resumen
}

Este artículo examina el tema de la deforestación en la Península de Freetown en Sierra Leona, enfatizando el vacío existente entre la retórica y las consecuentes políticas y proyectos derivados de ella. A lo largo del artículo se arguye que dicho vacío puede ser entendido mediante el estudio de los diferentes actores y su participación en el tema de la deforestación mediante la creación de políticas y proyectos. El análisis revela a dichos actores construyendo discursos de culpabilidad hacia los sectores más pobres de la población y a los grupos políticamente más débiles, dando como resultado que las propuestas de mitigación de la deforestación interfieran en la vida de los grupos más vulnerables. Dichas prescripciones de culpabilidad y la consecuente propuesta de soluciones son negociadas entre las realidades locales y la influencia de actores globales que promueven discursos de desarrollo e intervención. El análisis aquí presentado se enmarca dentro de la Ecología Política que desde una postura post-estructuralista revela cómo los discursos subyacentes, las acciones y los actores a lo largo de un amplio espectro político, económico y social juegan un rol primordial promoviendo las causas, las percepciones y las soluciones al problema de la deforestación.

Palabras clave: Deforestación, Ecología Política, Discursos, Desarrollo, Freetown, Sierra Leona, África

\section{Résumé}

Cet article examine la question de la déforestation sur la péninsule Freetown, Sierra Leone, en particulier l'analyse de l'écart qui existe entre la rhétorique qui entoure le problème de la déforestation et les politiques et les projets qui sont mis en œuvre pour y remédier. Il est soutenu dans cet article que cet écart peut être mieux compris en examinant comment les différents acteurs impliqués dans l'élaboration des politiques et des projets d'interagir sur la question de la déforestation. Cet analyse peut être révèle la façon dont ces acteurs produisent des discours de blâme envers les plus pauvres, les groupes les plus faibles politiquement, ce qui entraîne certains "solutions" qui interviennent dans leur vie. Ces prescriptions de la culpabilité et les solutions pour la déforestation sont négociés par le biais d'une combinaison des réalités locales, ce qui inclut l'apparition de la déforestation, et les influences mondiales telles que le discours de développement. L'analyse ici reflète une écologie politique ("political ecology") qui s'inspire également de la poststructuralisme et montre comment les idées qui sous-tendent les discours, les actions et les acteurs à travers un large consensus politique, social et économique. Cet analyse peut être, en fin de compte, jouer un rôle en influençant les causes, les perceptions et les solutions liées à la déforestation.

Mots-clés: déforestation, écologie politique, Freetown, discours de développement, Sierra Leone, l'Afrique 